\title{
Jus Post Bellum
}

\section{A Normative Framework for the Transition from Armed Conflict to Peace}

This chapter offers the conceptual basis for understanding jus post bellum as the normative framework for transition from armed conflict to peace. As presented in the Introduction, the origin and development of jus post bellum have taken place under a moral and a legal perspective. ${ }^{1}$ While within the just war theory the concept is built from the moral perspective of the justness of the cause and the termination of the conflict, under international law its purpose is to address legal obligations aimed at protecting people's rights in transition to peace. ${ }^{2}$

This chapter-and the study in general-focuses its analysis on the legal dimension of jus post bellum. Though the concept is being discussed in legal scholarship for around 15 years, ${ }^{3}$ there is no agreement on its content and scope as a legal concept. ${ }^{4}$ The discussion has moved from maximalist to minimalist approaches, ${ }^{5}$ including authors for whom it seems still premature to consider jus post bellum into law. ${ }^{6}$ In this context, Easterday, Iverson, and Stahn highlight that "there are almost as many conceptions of jus post bellum as scholars, within and across disciplines."7

1 See Introduction, Section 2.

2 Stahn, 'Jus Post Bellum: Mapping the Discipline(s),' 2008, 112.

3 The first works on jus post bellum from a legal perspective were conducted by Thürer and MacLaren, "Ius Post Bellum" in Iraq: A Challenge to the Applicability and Relevance of International Humanitarian Law?'; Boon, 'Legislative Reform in Post-Conflict Zones: Jus Post Bellum and the Contemporary Occupant's Law-Making Powers'; Cohen, 'The Role of International Law in Post-Conflict Constitution-Making: Toward a Jus Post Bellum for "Interim Occupations" '; Stahn, '“Jus Ad Bellum", "jus in Bello" ... "Jus Post Bellum"?-Rethinking the Conception of the Law of Armed Force'.

4 Iverson, 'The Function of Jus Post Bellum in International Law,' 8.

5 Lonneke Peperkamp, 'Jus Post Bellum: A Case of Minimalism versus Maximalism?', Ethical Perspectives 21, no. 2 (2014): 255-88.

6 Gregory Fox, 'Navigating the Unilateral/Multilateral Divide,' in Jus Post Bellum: Mapping the Normative Foundations, ed. Carsten Stahn, Jennifer Easterday, and Jens Iverson (Oxford: Oxford University Press, 2014), 229-58.

7 Easterday, Iverson, and Stahn, 'Exploring the Normative Foundations of Jus Post Bellum: An Introduction,' 3. 
This uncertainty undermines the development of the concept, which can also be attributed to the lack of empirical assessment. The only way to move forward from the theoretical discussion is to assess the concept in practice. As such, this chapter presents the main conceptions of jus post bellum as a legal concept across existing literature, addressing the approaches to a definition of the concept, its principles, its objective, its relationship with similar concepts, and its application in the context of transition from NIACs to peace-given the character of the case study. Then, the conceptual mapping provided by this chapter will be the reference for the empirical assessment of jus post bellum in the other two chapters of the study.

\section{1 \\ Approaches to a Definition}

Jus post bellum is a polysemous concept. ${ }^{8}$ The definitions and characterizations around the concept are diverse. Easterday defines jus post bellum as a broad and holistic category that covers four spectrums: "as a body of law, as an interpretive framework, as a site of coordination, and as a site of discourse or dialogue." ${ }^{9}$ For her, jus post bellum should be understood as referring to the rules, norms, and principles governing those spectrums in post-conflict with the goal of reaching sustainable peace.

In 2016, Stahn classified the existing definitions of jus post bellum under three approaches: 1) as a system of norms;2) as an ordering system; and 3) as an interpretative framework. ${ }^{10}$ This classification is similar to the four spectrums identified by Easterday if one considers the second approach as including both the spectrums of a site of coordination and a site of discourse or dialogue proposed by her. This section explores each of these approaches as follows.

\subsection{A New Legal Regime}

This approach is based on the alleged existence of a normative gap in the regulation of transition from armed conflict to peace. ${ }^{11}$ Its proponents sustain that

8 Emmanuel Vianès, 'Le Jus Post Bellum: Rupture Ou Continuité?', Études Internationales, 2013, 622. Iverson, 'The Function of Jus Post Bellum in International Law,' 8.

9 Jennifer Easterday, 'Peace Agreements as a Framework for Jus Post Bellum,' in Jus Post Bellum: Mapping the Normative Foundations, ed. Carsten Stahn, Jennifer Easterday, and Jens Iverson (Oxford: Oxford University Press, 2014), 379.

10 Stahn, 'Jus Post Bellum and the Justice of Peace: Some Preliminary Reflections.'

11 Orend, 'Jus Post Bellum,' 222; Stahn, 'Jus Post Bellum: Mapping the Discipline(s),' 2008, 101; Österdahl and van Zadel, 'What Will Jus Post Bellum Mean? Of New Wine and Old Bottles,' 182. 
such a gap ought to be fulfilled through new legal instruments. There is no discussion on accepting that jus post bellum does not exist as a defined branch of international law, as jus ad bellum and jus in bello do. However, the exponents of this approach sustain that jus post bellum should get such a status in international law. While most of them accept that this regime is based on existing norms of international law, all suggest that new norms should be created.

Orend is the main advocate of this approach. In 2000, at the very beginning of the contemporary discussion on jus post bellum, he argued the existence of a legal gap in the law of armed force. ${ }^{12}$ For him, this "situation requires rectification, ideally through the establishment of international laws of war termination which are codified and effectively observed."13 His idea was supported by DiMeglio, who considers that such a legal gap represents a risk that the "winner's justice can prevail," which may be addressed through a new legal regulation on the matter. ${ }^{14}$ Later, in 2007 , Orend proposed that this regulation should be done through a new Geneva Convention on jus post bellum. ${ }^{15}$

In the same line, Österdahl and van Zandel affirm that "new international laws, codified and effectively observed, are necessary in order to tackle the problems created by this legal gap in the regulation of post-conflict conduct,"16 and they suggest that it should be done "through the incorporation of all jus post bellum rules in a new Geneva Convention."17 At this regard, Österdahl noted that "the current post-conflict practice would necessarily provide a lot of experience and normative ideas that would fuel the negotiations on any such comprehensive legal instrument."18

This conception of jus post bellum is the most ambitious and contested one. ${ }^{19}$ Most authors disagree, or doubt that such a codification could be possible. ${ }^{20}$

12 Orend, War and International Justice: A Kantian Perspective.

13 Orend, 222.

14 DiMeglio, 'The Evolution of the Just War Tradition : Defining Jus Post Bellum,' 131-32.

15 Orend, 'Jus Post Bellum: The Perspective of a Just-War Theorist,' 591.

16 Österdahl and van Zadel, 'What Will Jus Post Bellum Mean? Of New Wine and Old Bottles,' 182.

17 Österdahl and van Zadel, 207.

18 Inger Österdahl, 'Just War, Just Peace and the "Jus Post Bellum", Nordic Journal of International Law 81, no. 3 (2012): 273.

19 Easterday, Iverson, and Stahn, 'Exploring the Normative Foundations of Jus Post Bellum: An Introduction,' $5^{-6 .}$

20 Among other authors, see Frederik Naert, 'International Humanitarian Law and Human Rights Law in Peace Operations as Parts of a Variable Ius Post Bellum,' Revue Belge de Droit International 44, no. 1-2 (2011): 26-37; De Brabandere, 'The Concept of Jus Post Bellum in International Law: A Normative Critique'; Bell, 'Of Jus Post Bellum and Lex Pacificatoria: What's in a Name?' 
And, indeed, codifying jus post bellum into a new convention seems an unlikely task, for at least three reasons.

First, a codification of jus post bellum will involve the ordinary political and practical challenges of a treaty-making process or the formation of customary law. ${ }^{21}$ It does not seem a likely task in a matter that by its very nature requires flexibility and the permanent balance of political and legal considerations, where states want to keep their autonomy. Additionally, peacemaking and peacebuilding are processes full of ambiguities and contradictions, that by no means could be addressed through a "conclusive body of law, i.e., as a (vertical) lex specialis." ${ }^{2}$ Peace is a political matter, and "the more law specifies peace settlement terms, the less the parties are able to negotiate."23

Second, even if some authors argue the existence of a legal gap, such a gap should not be understood as a lack of legal regulation, but of a framework to coordinate and to apply existing rules in a contextualized way in transitional settings. Transition from armed conflict to peace involves a diversity of matters that are already governed by rules belonging to different branches of international law. ${ }^{24}$ The application of any specific rule depends on each context, and it is not possible to regulate all of them by a singular branch of law. ${ }^{25}$ Different international norms play a role, even if they were not specifically designed to regulate transitions. Thus, the problem is not about lack of law, but how to coordinate and interpret those norms properly in transitional processes.

And third, even if jus post bellum appeared as a systemic adaptation of the current divide of the law of armed force, ${ }^{26}$ it is not possible to conceive the concept in the same way as jus ad bellum and jus in bello. These last two regimes operate in a top-down logic, where external norms are applied with no substantial margin of decision by the parties. On the contrary, in jus post bellum the parties take and adapt external norms according to the circumstances of their context. If we think, for instance, about jus in bello in NIACs,

21 De Brabandere, 'The Concept of Jus Post Bellum in International Law: A Normative Critique,' 136.

22 Carsten Stahn, 'The Future of Jus Post Bellum,' in Jus Post Bellum. Towards a Law of Transition from Conflict to Peace, ed. Carsten Stahn and Jann Kleffner (The Hague: T.M.C. Asser Press, 2008), 234. See also Hilary Charlesworth, 'Law After War,' Melbourne Journal of International Law 8, no. 2 (2007): 241.

23 Bell, 'Of Jus Post Bellum and Lex Pacificatoria: What's in a Name?', 200.

24 Chetail, 'Introduction'; Österdahl and van Zadel, 'What Will Jus Post Bellum Mean? Of New Wine and Old Bottles.'

25 Vianès, 'Le Jus Post Bellum: Rupture Ou Continuité?,' 632.

26 De Brabandere, 'The Concept of Jus Post Bellum in International Law: A Normative Critique,' 126. 
external imperative rules are required, since some parties in conflict-nonstate actors - usually do not recognize internal rules and institutions. Thus, to ensure the protection of minimum humanitarian standards, an external topdown regulation should be imposed without internal margin of appreciation or derogation by the parties. For that reason, there is a single jus in bello for all kind of NIACs, regardless of the causes or dynamics of the conflict. However, this is not the nature of jus post bellum. Even if some limits and standards are imposed by international law, they must be interpreted and applied in a way that allows the search of peace according to the conditions of the specific transitional context. In that way, jus post bellum involves a permanent bottom-up normative process, given by the way in which parties involved in transition apply and develop applicable international norms.

\subsection{Ordering System of Norms, Practices, and Discourses}

The second approach to a definition of jus post bellum recognizes that rather than new substantive law, an overarching framework for normative coordination and dialogue in transition is required. This framework should include norms to manage the interplay of applicable rules of international law from different legal branches and help to resolve eventual conflicts among them. ${ }^{27}$

Stahn points out that transition from conflict to peace "requires a multilayered structure, which addresses the sequencing and simultaneous application of different bodies of law (including peacetime law or domestic law, if needed). ${ }^{28}$ This interaction of different branches and levels of law in the post-conflict scenario demands an overarching framework providing rules of coordination. ${ }^{29}$ Along this line, Easterday argues that jus post bellum "can provide the needed coherence and determinacy in the post-conflict legal landscape,"30 serving two functions. First, jus post bellum offers a site of coordination, which "provides a space for a common legal language for the process of transition from conflict to peace, and a unified mode of interpretation for its different underlying legal frameworks when they are applied in post-conflict situations." ${ }^{31}$ Second, jus post bellum creates a site of discourse and dialogue, which "provides a way to connect different discourses dealing with issues of peace and conflict, and can create synergies between

27 Chetail, 'Introduction,' 18.

28 Stahn, 'The Future of Jus Post Bellum,' 234.

29 Chetail, 'Introduction,' 18.

30 Easterday, 'Peace Agreements as a Framework for Jus Post Bellum,' 385.

31 Easterday, 383. 
disciplines such as international relations, legal anthropology, political science, and peace and conflict studies." ${ }^{32}$

Sari goes even further and describes jus post bellum "as a normative process which envisages the progressive evolution of the legal framework applicable to post-conflict situations over a period of time." 33 In this sense, the concept should offer elements to identify relevant rules and principles and help to balance them in a concrete context of transition. Similarly, Vatanparast considers jus post bellum as "a concept of mixed utility", which offers a "conceptual space" to hold the debate on the "complexities of warfare and the evolving relationships between law, war, and peace." 34

In a critic to this approach-and to jus post bellum in general-, De Brabandere sustains that this view has been justified arguing that jus post bellum helps "bringing the existing rules and obligations to the forefront of legal discussion and political decision making." ${ }^{35}$ However, for him, such a conception would mean that jus post bellum "simply brings together already existing obligations under a new name, ${ }^{36}$ without any "added value from a purely legal perspective." ${ }^{37}$

Based on the discussed elements, this approach offers important insights to understand jus post bellum in systemic terms. The disparate set of rules applying in transitional contexts requires some integration. Thus, if jus post bellum operates as an overarching system to group those norms and regulate their interplay, the concept would provide such an integration and coordination of norms. However, gathering the norms applicable to the transition from armed conflict to peace is a useful step, but it does not offer a legal function by itself. The next approach offers complementary elements in that direction.

32 Easterday, $383-84$.

33 Sari, 'The Status of Foreign Armed Forces Deployed in Post-Conflict Environments: A Search for Basic Principles,' 482-83.

34 Roxana Vatanparast, 'Waging Peace: Ambiguities, Contradictions, and Problems of a Jus Post Bellum Legal Framework,' in Jus Post Bellum: Mapping the Normative Foundations, ed. Carsten Stahn, Jennifer Easterday, and Jens Iverson (Oxford: Oxford University Press, 2014), 153 .

35 De Brabandere, 'The Concept of Jus Post Bellum in International Law: A Normative Critique,' 137 .

36 Eric De Brabandere, 'The Responsibility for Post-Conflict Reforms: A Critical Assessment of Jus Post Bellum as a Legal Concept,' Vanderbilt Journal of Transnational Law 43, no. 1 (2010): 122.

37 De Brabandere, 'The Concept of Jus Post Bellum in International Law: A Normative Critique,' 137 . 


\subsection{Interpretative Framework}

In 2009, Chetail pointed out how jus post bellum serves as a framework for the "contextualized interpretation" of existing norms applicable to the transition from armed conflict to peace. ${ }^{38}$ This interpretative approach to the concept was then developed by James Gallen, ${ }^{39}$ defining jus post bellum "as an interpretive framework for international law through the various dimensions of complexity that arise in transitions." ${ }^{40}$ For him, "the distinctive value of jus post bellum should be in recognizing that the various norms, regulations, and practices relevant to transitions are inter-dependent and mutually re-enforcing and as a result can be evaluated and interpreted in a unified fashion." ${ }^{41}$ As such, he argues that this framework integrates three dimensions of complexity that must be addressed in transition: 1 ) the variety of legal obligations that apply in transitions; 2) the international legal status of actors involved in the process; and 3 ) the particularities of each transitional context. ${ }^{42}$

Although Gallen considers a suitable end the development of a codification on jus post bellum, he agrees that it would be difficult to achieve. ${ }^{43}$ Nevertheless, he points out that "the absence of a conventional jus post bellum does not preclude the interpretation of existing international law and policy" under a unified framework. ${ }^{44}$

On this point, even if De Brabandere is skeptical about jus post bellum, he admits that this minimalistic approach to the concept as an interpretative framework is "theoretically is the most viable." ${ }^{45}$ For him, under this perspective jus post bellum responds to the "need to interpret uniformly the various norms, rules, and practices applicable in post-conflict reconstruction," and

38 Chetail, 'Introduction,' 18.

39 James Gallen, 'Jus Post Bellum: An Interpretive Framework,' in Jus Post Bellum: Mapping the Normative Foundations, ed. Carsten Stahn, Jennifer Easterday, and Jens Iverson (Oxford: Oxford University Press, 2014), 58-79.

40 Gallen, 59 .

41 Gallen, 59.

42 Gallen, 61-65.

43 In a later article, he admits that in the future jus post bellum could lead to a codification into a Geneva Convention or in policy documents. In his words, "jus post bellum may eventually lead to concrete changes in existing public international law and find expression in a future Geneva Convention or in the policy documents of international organisations. At present it may effectively operate as an interpretation of the laws, actors, issues and fields relevant to the achievement of a just and sustainable peace after conflict." James Gallen, 'Odious Debt and Jus Post Bellum,' Journal of World Investment \& Trade 16, no. 4 (2015): 670.

44 Gallen, 'Jus Post Bellum: An Interpretive Framework,' 69.

45 De Brabandere, 'The Concept of Jus Post Bellum in International Law: A Normative Critique,' 127 . 
thus it should be seen "as a normative set of principles rather than substantive rules." ${ }^{46}$ As such, he suggests the identification of existing principles of international law relevant to transition for interpreting applicable "rules in function of the identified overarching principles." ${ }^{47}$

Similarly, although Bell has proposed the concept of lex pacificatoria as an alternative to jus post bellum, ${ }^{48}$ her approach is close to the notion of an interpretative framework. She says that the emerging lex is the result of the evolution of legal understandings on how international law should be applied to peace processes and agreements. As such, rather than "regulate negotiations outcomes," this lex sets out normative parameters that offer the elements to reach agreements combining the specific needs of justice and peace. ${ }^{49}$ In her words, "this new lex does not operate as a clear new legal regime establishing a set of legal obligations but rather as a set of programmatic standards that provides guidance and, at times, goes further in creating a normative expectation as to how the dilemmas of peace settlements can be resolved concomitantly with the requirements of international law."50

This approach is the most accurate in terms of identifying the legal function of jus post bellum. It does not call for new norms but for a framework to interpret the existing norms of international law in a consistent and contextualized way in transitional settings. ${ }^{51}$ This interpretative function is required to resolve conflicts between a general legal norm, on the one hand, and the specific conditions of post-conflict contexts in which such a norm should be applied, on the other. However, this approach takes elements from the previous one, since the interpretative function played by jus post bellum implies an ordering system or a space of dialogue to combine legal and practical considerations to achieve the adequate formula for a particular context of transition.

As such, combining elements from the last two approaches, an integrative definition becomes possible. Jus post bellum can be seen, then, as a normative framework ordering norms, discourses, and practices to allow the contextualized interpretation and application of relevant international law to the transition from armed conflict to sustainable peace. With this idea on mind, the study will continue exploring elements from theory and practice in the first

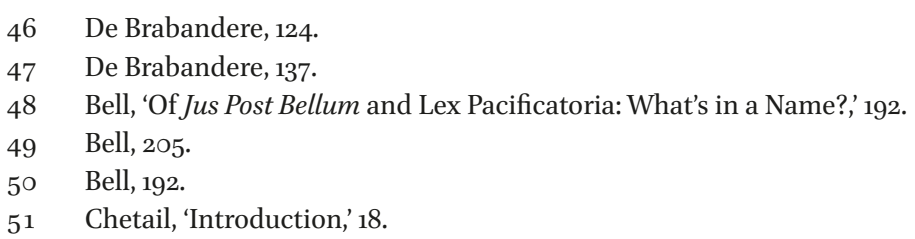


two chapters, and then it will develop its own approach to the definition and content of jus post bellum in Chapter 3 from the perspective of the case study.

\section{Principles of Jus Post Bellum}

Regardless of their approach to a definition, most authors have proposed different series of principles of jus post bellum. While just war theorists have suggested moral principles informing the conditions to reach a just peace, in legal scholarship principles have been proposed with various purposes. Authors claiming for the codification of jus post bellum through a new conventional instrument suggest principles to develop such a body of law. Authors understanding jus post bellum as an ordering framework propose overarching principles to organize the disparate set of norms applicable to transitional contexts. And authors approaching jus post bellum as an interpretative framework argue that principles are the tool for interpreting international law in a contextualized way in transitional settings.

For Stahn, the configuration of a jus post bellum framework would allow to identify "specific legal principles which serve as guidance in making legal policy choices in situations of transitions." 52 To this effect, in one of his first works on the topic, he proposed six principles of jus post bellum: 1) Fairness and inclusiveness of peace settlements; 2) Demise of the concept of punishment for aggression; 3) Humanization of reparations and sanctions; 4) Moving from collective to individual responsibility for wrongs committed during conflict; 5) Combining justice and reconciliation models; and 6) Fostering people-centered governance. ${ }^{53}$ Similarly, Orend suggests as jus post bellum principles: 1) Rights vindication; 2) Proportionality and publicity, 3) Discrimination between leader, soldiers and civilians, 4) Punishment, 5) Compensation, and 6) Rehabilitation. ${ }^{54}$

In the context of post-occupation situations, where the concept of jus post bellum started its contemporary development, principles related to occupiers'

52 Stahn, 'Jus Post Bellum: Mapping the Discipline(s),' 2008, 101-2.

53 Stahn, “"Jus Ad Bellum", "jus in Bello" ... "Jus Post Bellum"?-Rethinking the Conception of the Law of Armed Force,' 938-41.

54 Brian Orend, 'Jus Post Bellum: A Just War Theory Perspective,' in Jus Post Bellum. Towards a Law of Transition from Conflict to Peace, ed. Carsten Stahn and Jann Kleffner (The Hague: T.M.C. Asser Press, 2008), 37-42. In a previous work, Orend suggested five principles of jus post bellum: 1) Just cause for termination; 2) Right intention; 3) Public declaration and legitimate authority; 4) Discrimination; and, 6) Proportionality. Orend, 'Jus Post Bellum,' 128-29. 
duties have been proposed. Boon suggests three principles: trusteeship, accountability, and proportionality. ${ }^{55}$ And later, Coady proposed other three: rebuilding and reconstruction, punishment and reparations, and the role of occupiers, peacemakers and peacekeepers. ${ }^{56}$

Gallen and De Brabandere, who define jus post bellum as an interpretative framework, also suggest their principles. For Gallen, jus post bellum should be based on three principles: accountability (individual criminal responsibility and state responsibility), stewardship (respect of local ownership), and proportionality. ${ }^{57}$ In a similar formulation, De Brabandere coincides with those principles, that he describes as proportionality, accountability of foreign actors (he is focused on post-occupation), and the principle that post-conflict reconstruction should be for the benefit of the population..$^{58}$

Just as there is no agreed definition, there is no agreement in terms of jus post bellum principles. The above-mentioned principles have been formulated in general ways, in works aimed at discussing conceptual aspects of jus post bellum. There is no a systematic analysis on these principles, and each author suggests new ones without discussing principles formulated previously. Additionally - as common with other aspects of the existing legal scholarship on jus post bellum - the principles which have been proposed are mainly addressed to IACs. This situation does not correspond to the fact that NIACs are currently more common than IACs nor to the need to provide greater consistency to the concept of jus post bellum.

In his 2012 book After War Ends: A Philosophical Perspective, May developed a systematic scheme of six principles of jus post bellum: rebuilding, retribution, restitution, reparation, reconciliation, and proportionality..$^{59}$ These principles integrate some of the principles proposed by other authors, and his proposal has received significant endorsement by other scholars. ${ }^{60}$

55 Boon, 'Legislative Reform in Post-Conflict Zones: Jus Post Bellum and the Contemporary Occupant's Law-Making Powers'.

56 Cecil Anthony Coady, 'The Jus Post Bellum,' in New Wars and New Soldiers: Military Ethics in the Contemporary World, ed. Jessica Wolfendale and Paolo Tripodi (London: Ashgate Press, 2011), 49-66.

57 Gallen, 'Jus Post Bellum: An Interpretive Framework'.

$5^{8}$ De Brabandere, 'The Concept of Jus Post Bellum in International Law: A Normative Critique,' $137-38$.

59 May, After War Ends.

6o Among the authors referring May's principles as a base to develop jus post bellum, see: Easterday, Iverson, and Stahn, 'Exploring the Normative Foundations of Jus Post Bellum: An Introduction'; Matthew Saul, 'Creating Popular Governments in Post-Conflicts Situations: The Role of International Law,' in Jus Post Bellum: Mapping the Normative Foundations, ed. Carsten Stahn, Jennifer Easterday, and Jens Iverson (Oxford: Oxford 
For May, these normative principles are the constituent substance of jus post bellum. However, since his proposal was conceived under the perspective of the just war theory, he considers that the normative character of these principles derives not from law but from moral. In his words,

Jus post bellum principles are primarily moral principles that are meant to inform decisions about how international law is best to be established down the road. Here it is important to note that on this construal, jus post bellum principles are not legal principles themselves. Jus post bellum principles are normative in that they are moral norms and they tell us what should become law. But until there is some lawmaking act, such as an international convention (a multilateral treaty), what I will identify as jus post bellum principles are primarily moral norms that have strong force in our thinking about what norms should be enacted into international law. [...] In setting out a group of jus post bellum principles I am making a plea for them to become instituted, but my arguments in favor of having them become legal norms should not be confused with thinking that they already have legal status, which they do not. ${ }^{61}$

Sustaining this idea, in a later article May argues that the proposed set of jus post bellum principles is comparable to the content and scope of the Martens Clause to The Hague Convention (II). ${ }^{62}$ As such, he states that even if jus post bellum principles are not yet enshrined in legal instruments, they are the embodiment of moral obligations written in the human conscience that dictates the way to proceed in post-conflict settings. In consequence, for him, jus

University Press, 2014), 447-66; Fionnuala Ní Aoláin and Dina Haynes, 'The Compatibility of Justice for Women with Jus Post Bellum Analysis,' in Jus Post Bellum: Mapping the Normative Foundations, ed. Carsten Stahn, Jennifer Easterday, and Jens Iverson (Oxford: Oxford University Press, 2014), 161-77; Stahn, 'Jus Post Bellum and the Justice of Peace: Some Preliminary Reflections'. Iverson, 'The Function of Jus Post Bellum in International Law,' 8.

61 May, After War Ends, 5 .

62 May, 'Jus Post Bellum, Grotius, and Meionexia,' 24. On this point, the Martens Clause is formulated in the following terms: "Until a more complete code of the laws of war is issued, the High Contracting Parties think it right to declare that in cases not included in the Regulations adopted by them, population and belligerents remain under the protection and empire of the principles of international law, as they result from the usages established between civilized nations, from the laws of humanity and the requirements of the public conscience". Preamble, Hague Convention (II) Respecting the Laws and Customs of War on Land (adopted 29 July 1899, entered into force 4 September 190o). 
post bellum is "a regime of international law that is not strictly speaking lex lata but is also more than mere lex ferenda."63

In the 2014 publication of the Jus Post Bellum Project, its editors acknowledge that May's principles constitute a solid basis for jus post bellum. Nonetheless, they point out that "the question remains: (how) are those moral norms reflected in international law?"64

Regarding this matter, May's principles are certainly useful and they offer a strong basis to reach a unified approach to the content and scope of jus post bellum. ${ }^{65}$ However, contrary to May's view on the exclusive moral nature of these principles, they already have a basis in international law. ${ }^{66}$ To this effect, through Chapters 2 and 3 the study will explore the legal foundation of the principles of jus post bellum in contexts of NIACs, and their role in coordinating, interpreting, and applying international legal obligations in the Colombian transition from armed conflict to peace. ${ }^{67}$ Along this line, Saul argues that we need to explore in practice the legal components of jus post bellum following May's principles, to give them "a more concrete form without completely loosing" their inherent flexibility. ${ }^{68}$

63 May, 23. Supporting the idea of jus post bellum as being moral, but not having a legal basis, see also: Antonia Chayes, 'Chapter VII⿳1⁄2: Is Jus Post Bellum Possible?,' European Journal of International Law 24, no. 1 (2013): 293.

64 Easterday, Iverson, and Stahn, 'Exploring the Normative Foundations of Jus Post Bellum: An Introduction,' 1.

65 At this point, it is important to clarify that even if this study addresses jus post bellum form a legal perspective, as stated before, it does not exclude the reference to elements proposed under the just war theory, as they are expressed in international law. In this line, Stahn evokes that is "wrong to construe a 'moral' and a 'legal' jus post bellum in isolation from each other. There are important and justified differences between the two. But none of them is completely detached from the other". Stahn, 'The Future of Jus Post Bellum,' 232.

66 In the case of jus ad bellum and jus in bello, their legal principles and rules were originally conceived as moral duties, which were later translated into positive and customary legal obligations. So, even if the nature of jus post bellum is different, its development was also initially grounded in a moral perspective. But, as sustained by Evans, moral principles look to "animate the body of law that constitutes 'legal' jus post bellum", Mark Evans, 'At War's End: Time to Turn to Jus Post Bellum?', in Jus Post Bellum: Mapping the Normative Foundations, ed. Carsten Stahn, Jennifer Easterday, and Jens Iverson (Oxford: Oxford University Press, 2014), 26.

67 Chapter 2 will offer the legal framework on the main components of the Colombian peace agreement. Then, Chapter 3, Section 3, will address the principles of jus post bellum as they are viewed in the Colombian transition. However, the legal foundation of those principles is referred mainly in Chapter 2.

68 Saul, 'Creating Popular Governments in Post-Conflicts Situations: The Role of International Law,' 466. 
Different views support this argument on the legal foundation of jus post bellum principles. Jus post bellum is based on existing principles and rules of international law, which are inspired on a liberal view of law centered in the protection of the individual and his fundamental rights. ${ }^{69}$ On this point, Österdahl affirms that jus post bellum "could gradually lead to new organizing principles" around democracy, the rule of law, and human rights. ${ }^{70}$ Similarly, authors as Walzer ${ }^{71}$ and Williams and Caldwell ${ }^{72}$ coincide sustaining that human rights are the foundation of jus post bellum principles. Even May affirms that these principles are aimed at building a just peace, which for him means that "human rights are protected."73

Considering this background, this study sustains that principles express the substantive content of jus post bellum. As such, Chapter 3 will analyze each of the principles proposed by May, along with some other principles proposed by other authors, assessing how they are reflected in the Colombian case, according to the practice analyzed in Chapter $2 .{ }^{74}$

The very use of the concept of jus post bellum is problematic to refer a matter that is transitional by nature. Scholars agree that notwithstanding jus post bellum is intended to apply to the post-conflict phase, it is not clear how to determine when does it occur. ${ }^{75}$ At this regard, Kennedy considers the term

69 For a literature review on the liberal dimension of peacebuilding, see Chetail and Jütersonke, 'Peacebuilding: A Review of the Academic Literature,' $5^{-}$-7. Chetail specifically relates this liberal view to the legal foundation of jus post bellum, since he defines jus post bellum as the normative framework of peacebuilding: Chetail, 'Introduction.'

70 Inger Österdahl, 'The Gentle Modernizer of the Law of Armed Conflict,' in Jus Post Bellum: Mapping the Normative Foundations, ed. Carsten Stahn, Jennifer Easterday, and Jens Iverson (Oxford: Oxford University Press, 2014), 209.

71 Michael Walzer, 'The Aftermath of War. Reflections on Jus Post Bellum,' in Ethics Beyond War's End, ed. Eric Patterson (Washington: Georgetown University Press, 2012), 43.

72 Williams and Caldwell, 'Jus Post Bellum: Just War Theory and the Principles of Just Peace,' 309 .

73 May, After War Ends, 86. On this line, he asserts that jus post bellum principles look to guarantee the human rights of the people affected by the conflict, "as well as the human rights of the people of the world." May, 22.

74 As previously mentioned, in Chapter 2 the study will offer the legal framework on the main components of the Colombian Peace Agreement, which will then be addressed in Chapter 3, Section 3, identifying principles of jus post bellum in the Colombian transition.

75 Vatanparast, 'Waging Peace: Ambiguities, Contradictions, and Problems of a Jus Post Bellum Legal Framework,' 146; Carsten Stahn, 'Jus Post Bellum: Mapping the Discipline(s),' American University International Law Review 23, no. 2 (2007): 322; Doug McCready, 
post-conflict inadequate, since the process of transition is a series of continuities where is not possible to determine the end of war or the beginning of peace. ${ }^{76}$

The transition from conflict to peace is a process with no clear starting and ending points. ${ }^{77}$ This problem is common in all jus ad bellum, jus in bello, and jus post bellum, ${ }^{78}$ since the before, the during, and the after of armed confrontation are usually complex and no linear periods. But, the very name of jus post bellum implies a temporary dimension. On this point, Stahn admits that "the 'post' in this equation is a fragile concept."79

The application of jus post bellum does not depend on the end of the conflict or the cessation of the application of jus in bello. Determining the end of armed conflicts is a complicated matter under IHL. Article Common 3 and Protocol Additional II do not say anything on this matter, and the main criteria to determine the end of the conflict are: 1) the decreasing intensity of the confrontation, ${ }^{80}$ or, 2) a peace settlement establishing the end of hostilities. ${ }^{81}$ However, the end of a NIAC does not imply the automatic cessation of the application of humanitarian provisions. Some matters keep being regulated by humanitarian norms when their effects last longer than the end of the conflict—such as questions of landmines, displaced persons, or missing

'Ending the War Right: Jus Post Bellum and the Just War Tradition,' Journal of Military Ethics 8, no. 1 (2009): 75; Österdahl and van Zadel, 'What Will Jus Post Bellum Mean? Of New Wine and Old Bottles,' 175-76; Stahn, “"Jus Ad Bellum", "jus in Bello" ... "Jus Post Bellum"? - Rethinking the Conception of the Law of Armed Force,' 923.

76 David Kennedy, Of War and Law (Princeton: Princeton University Press, 2006), 113-14.

77 Jan Kleffner, 'Towards a Functional Conceptualization of Temporal Scope of Jus Post Bellum,' in Jus Post Bellum: Mapping the Normative Foundations, ed. Carsten Stahn, Jennifer Easterday, and Jens Iverson (Oxford: Oxford University Press, 2014), 288-89.

78 Martin Wählisch, 'Conflict Termination from a Human Rights Perspective: State Transitions, Power-Sharing, and the Definition of the "Post", in Jus Post Bellum: Mapping the Normative Foundations, ed. Carsten Stahn, Jennifer Easterday, and Jens Iverson (Oxford: Oxford University Press, 2014), 317.

79 Stahn, 'The Future of Jus Post Bellum,' 233.

8o For Bartels, "if a NIAC only starts when organized armed groups are engaged in fighting of a certain degree of intensity, then, logically, the armed conflict ends when these two criteria are no longer present." Rogier Bartels, 'From Jus in Bello to Jus Post Bellum: When Do Non-International Armed Conflicts End?', in Jus Post Bellum: Mapping the Normative Foundations, ed. Carsten Stahn, Jennifer Easterday, and Jens Iverson (Oxford: Oxford University Press, 2014), 303 .

81 Gabriella Venturini, 'The Temporal Scope of Application of the Conventions,' in The 1949 Geneva Conventions, ed. Andrew Clapham, Paola Gaeta, and Marco Sassoli (Oxford: Oxford University Press, 2015), 61-62. 
people. ${ }^{82}$ As such, Bartels sustains that it is not necessary to wait until jus in bello ceases to apply to start applying jus post bellum, and thus both regimes could apply simultaneously. ${ }^{83}$

A more complicated question concerns to the determination of the end of applicability. If jus post bellum is a law of transition from armed conflict to peace, it could be said that it ceases to apply when there is peace. ${ }^{84}$ Regarding this matter, Kleffner considers that if the purpose of jus post bellum is to establish sustainable peace, jus post bellum would cease to apply when conflict has been addressed to a point in which there is no risk to come back to violence. ${ }^{85}$ He says that there are some components of jus post bellum for which it would be possible to identify an end, such as criminal proceedings, reparations to victims, and disarmament and demobilization. Nevertheless, all those processes do not happen at the same time. ${ }^{86}$ The question would be even more difficult regarding matters of positive peace.

As such, Kleffner proposes a functional approach to determine the temporal scope of jus post bellum, which he sees as a body of law. Since this regime applies to transitional environments, "its applicability ratione temporis is equally transitional." ${ }^{87}$ Thus, the temporal scope should be regarded in a flexible way, because even if some components have a clear end, others last over the time.

Indeed, transitional periods are fluids, and therefore it is difficult-if not impossible— to establish a temporal scope. ${ }^{88}$ On this point, Wählisch argues that the "continuum of practical and legal dynamics [...] set the 'post' into a relative state." ${ }^{89}$ However, he suggests some criteria to determine the end of jus post bellum application through the reestablishment of human rights guarantees: completed elections, constitutional amendments, compliance with human rights conventional obligations, return of internally displaced persons, etc. ${ }^{90}$

82 Venturini, 61; ICRC, Commentary on the First Geneva Convention, 2nd edition, 2016, para. $85^{\circ}$.

83 Bartels, 'From Jus in Bello to Jus Post Bellum: When Do Non-International Armed Conflicts End?', 314.

84 Kleffner, 'Towards a Functional Conceptualization of Temporal Scope of Jus Post Bellum,' 293.

85 Kleffner, 293-94.

86 Kleffner, 294-95.

87 Kleffner, 295 .

88 Wählisch, 'Conflict Termination from a Human Rights Perspective: State Transitions, Power-Sharing, and the Definition of the "Post"', 316.

89 Wählisch, 318.

$90 \quad$ Wählisch, 321. 
Similarly, other authors consider the question of the temporal scope of jus post bellum from a functional angle. Iverson emphasizes that what matters "from a jus post bellum perspective is not whether a status of post bellum has technically been achieved but rather whether legal norms are being applied with post bellum as the goal." ${ }^{91}$ Along these lines, May sustains:

We should be flexible on how we regard the 'post', mainly in contexts where there is not a formal ending of war. [...] Jus post bellum refers to any principles that govern the mopping up efforts, namely the efforts at the end and after the end of war that lead into a position of peace. In this way, we don't have to decide precisely when war ends but only when the practices of mopping up begin. It is conceivable that mopping up efforts occur even while it is pretty clear that war is still waging, although often this will be a very dangerous thing to do. ${ }^{92}$

The overall discussion on a temporal or a functional approach in the application of jus post bellum is closely connected to the meaning given to the concept. The question of the temporal scope is particularly relevant under the approach to jus post bellum as an independent legal regime. However, if one sees jus post bellum under other approaches, the focus shifts to a functional rather than a temporal application. In jus post bellum as an ordering system or as an interpretative framework, there is no need to discuss a temporal applicability. Under these approaches, jus post bellum plays a role guiding the application of norms in the process of transition from armed conflict to peace, but it does not constitute a corpus of norms applicable by itself.

In this way, rather than a legal order with specific ratione temporis application, jus post bellum is a framework offering a space to coordinate and apply relevant norms to the process of transition from armed conflict to peace. This vision conveys a functional and teleological perspective. It means that, instead of a temporal frame of application, jus post bellum involves the function and the goal of applying law to end armed conflict and build sustainable peace.

On this point, it is relevant the above-quoted May's idea, arguing that "jus post bellum refers to any principles that govern the mopping up efforts [...] that lead into a position of peace."93 Therefore, there is no need to determine

91 Iverson, Jens, 'Transitional Justice, Jus Post Bellum and International Criminal Law: Differentiating the Usages, History and Dynamics,' The International Journal of Transitional Justice 7 (2013): 426.

92 May, After War Ends, 3.

93 May, 3 . 
"when war ends but only when the practices of mopping up begin."94 As such, the principles of jus post bellum embody a set of legal standards, practices, and discourses guiding the application of law in transitional processes, which could occur during the ongoing conflict, through a peace process, or during the implementation of a peace agreement. This question is particularly visible in the Colombian case, where several elements of jus post bellum can be identified in the legal regulation of matters like reparation and criminal justice during the conflict. ${ }^{95}$ Similarly, the framework of jus post bellum guided the recent peace process in Colombia and its 2016 Peace Agreement even if armed conflict continues in the country, since, at least, one rebel group remains in hostilities. ${ }^{96}$

In consequence, there is no need to establish a beginning or an end in the application of jus post bellum. This question is rooted in the function played by jus post bellum rather than in a temporal sequence. ${ }^{97}$ As such, the concept covers the normative framework guiding the transition from armed conflict towards sustainable peace, regardless of the existence of a peace process or the effective end of the conflict.

\section{The Object of Jus Post Bellum}

Determining the goal pursued by jus post bellum is an essential task to develop its functional approach. As delineated in the previous sections, regardless of the approach to a definition, the concept has been conceived as a normative framework to guide societies emerging from armed conflict to reach a solid peace.

Under the just war theory, the concept is linked to the justness of peace and, thus, interconnected and interdependent to jus ad bellum and jus in bello. ${ }^{98}$

\section{May, 3.}

95 Different legal transitional instruments in Colombia can be seen as having a jus post bellum approach, even if they were adopted during the ongoing armed conflict, and with no peace agreement in mind. See: Congreso de la República de Colombia, Ley 975 (Ley de Justicia y Paz), 2005; Congreso de la República de Colombia, Ley 1448 (Ley de Víctimas y Restitución de Tierras); Congreso de la República de Colombia, 'Acto Legislativo or de 2012 (Marco Jurídico Para La Paz)' (2012).

96 Despite the broad scope of the 2016 Peace Agreement, another guerrilla goup (the ELN) remains in hostilities in the country. Chapter 2, Section o, will offer an overview of the Colombian armed conflict.

97 Iverson, 'The Function of Jus Post Bellum in International Law,' 13.

98 Walzer, Just and Unjust Wars. A Moral Argument with Historical Illustrations; May, After War Ends, 220. 
For Orend, one must consider the justice of the resort to war, the justice in the conduct of war, and the justice after war. ${ }^{99}$ In the same way, May suggests that "nearly everyone to have written on the subject of war would agree that the object of a just war is the achievement of a just and lasting peace." 100 Similarly, Walzer sustains that jus post bellum implies to have a look at the justice of war's goals, ${ }^{101}$ and Lucas even affirms that jus post bellum "includes the demand for a right intention to both fight and conclude wars with justice."102 Lastly, Labonte states that for a just war theorist jus post bellum matters because "how war ends-including the substantive terms of a negotiated peace agreement-can be a key factor in determining its justness."103

However, such an approach to the objective of jus post bellum is problematic from a legal point of view. The notion of the justness of peace is rooted in the moral tradition of the just war theory, and it would be difficult to apply it in a legal perspective. Additionally, international law has understood jus ad bellum, jus in bello, and jus post bellum as independent legal frameworks. ${ }^{104}$ Contrary to the just war theory's conception on the linear justness of the three regimes, international law sustains that each regime is independent, and must be observed regardless of the others. It means that the breach of one of them does not imply that the others are consequently broken too.

On this perspective, Vatanparast affirms that "jus post bellum is thought to provide a legal framework that can address the underlying causes of conflict to prevent relapse into hostilities." 105 Thus, the object of jus post bellum goes beyond the end of hostilities and looks at creating long-term peace. As such, she sustains that the concept's goal is "to eliminating the root causes of conflict and creating a lasting peace." 106 Stahn shares a similar view, arguing that a "modern jus post bellum would be focused on the sustainability of peace, rather than on simply brokering an end to violence."107 This

\footnotetext{
99 Orend, 'Jus Post Bellum,' 118.

100 May, After War Ends, 10.

101 Walzer, Just and Unjust Wars. A Moral Argument with Historical Illustrations.

102 George Lucas, 'Jus Ante and Post Bellum. Completing the Circle, Breaking the Circle,' in Ethics Beyond War's End, ed. Eric Patterson (Washington: Georgetown University Press, 2012), 6o.

103 Labonte, 'Jus Post Bellum, Peacebuilding and Non-State Actors : Lessons from Afghanistan,' 208.

104 Stahn, “Jus Ad Bellum", "jus in Bello" ... "Jus Post Bellum"? — Rethinking the Conception of the Law of Armed Force,' 925.

105 Vatanparast, 'Waging Peace: Ambiguities, Contradictions, and Problems of a Jus Post Bellum Legal Framework,' 144.

106 Vatanparast, 145 .

107 Stahn, 'Jus Post Bellum: Mapping the Discipline(s),' 2008, 107.
} 
perspective is reaffirmed in the 2017 Jus Post Bellum Project's volume, where its editors state that "the concept is inherently liked to the idea of sustainable peace."108

Österdahl affirms that "the purpose of jus post bellum is to achieve a just and stable peace based on democracy, human rights and the rule of law."109 Even though she uses the notion of just peace, she grounds her view on legal elements. In another article authored by her and by van Zadel, they expose this viewpoint in further detail. For them,

The aim of the rules of jus post bellum is to achieve a durable peace by helping the state return to its sovereign pre-conflict situation, if such was a desirable one measured by standards of international law, or by helping the state achieve an improved version of its pre-conflict situation. Ideally, the state should achieve a higher level of human rights protection, accountability and good governance in the post-conflict phase than in the period before the conflict. ${ }^{110}$

According to the above-discussed elements, one can conclude that the final goal of jus post bellum is not simply about ending conflict but about establishing a qualified and sustainable peace. ${ }^{111}$ On this matter, the UN General Assembly has noted that:

'Peace' is understood as meaning sustainable peace.

While the cessation of hostilities, restoration of public security and meeting basic needs are urgent and legitimate expectations of people who have been traumatized by armed conflict, sustainable peace requires a long-term approach that addresses the structural causes of conflict, and promotes sustainable development, rule of law and governance, and

108 Carsten Stahn, Jens Iverson, and Jennifer Easterday, 'Introduction: Protection of the Environment and Jus Post Bellum: Some Preliminary Reflections,' in Environmental Protection and Transitions from Conflict to Peace: Clarifying Norms, Principles, and Practices, ed. Carsten Stahn, Jens Iverson, and Jennifer Easterday (Oxford: Oxford University Press, 2017), 7 .

109 Österdahl, 'The Gentle Modernizer of the Law of Armed Conflict,' 208.

110 Österdahl and van Zadel, 'What Will Jus Post Bellum Mean? Of New Wine and Old Bottles,' 179 .

111 Chetail, 'Introduction,' 18; Iverson, Easterday, and Stahn, 'Epilogue: Jus Post BellumStrategic Analysis and Future Directions,' 548; Boon, 'The Application of Jus Post Bellum in Non-International Armed Conflicts,' 265. 
respect for human rights, making the recurrence of violent conflict less likely. ${ }^{112}$

In the same view, referring to his guidelines to UN peace envoys, the UN Secretary-General noted that his envoys "can assist in brokering agreements in conformity with law and in a manner which may provide the basis for lasting peace."113 It involves Galtung's idea of reaching not only negative but also positive peace. ${ }^{114}$ In other words, in this context peace "means long-term peace."115

In conclusion, the object of jus post bellum must be understood in terms of offering a normative framework for societies in transition to establishing a sustainable peace, which requires, at least, two conditions. First, addressing the root causes of the conflict, which is the only way to promote reconciliation and prevent recurrence to violence. Second, observing relevant standards of international law, which are essential to ensure the rule of law, human rights, governance, and international legitimacy.116

Both conditions can be appreciated in the Colombian transition. A comprehensive peace process was conceived for both addressing the root causes of the armed conflict and dealing with its consequences in terms of justice, truth, and reparation under an international legal framework. Chapter 2 will analyze how the root causes and the consequences of armed conflict were addressed in Colombia, integrating legal, political, and practical considerations. Then, Chapter 3 will discuss how the Colombian experience offers empirical elements to delineate the object of jus post bellum as presented in this section.

\section{5}

\section{Jus Post Bellum and Related Concepts}

In addition to the critics around its definition and scope, jus post bellum is challenged by the existence of other concepts related to the transition from armed conflict to peace. There are several notions associated to transitional

\footnotetext{
112 UN General Assembly, 'Nuremberg Declaration on Peace and Justice,' Pub. L. No. A/62/ 885 (2008), II.1.

113 United Nations, "press Release: Secretary-General Comments on Guidelines Issued to Envoys," UN Doc. SG/sm/7257 (10 December 1999).

114 Johan Galtung, 'Violence, Peace, and Peace Research,' Journal of Peace Research 6, no. 3 (1969): 167-91.

115 Chetail and Jütersonke, 'Peacebuilding: A Review of the Academic Literature,' 1.

116 On this question, Kastner sustains that "respecting legal obligations confers legitimacy and increases the effectiveness of peace negotiations and eventually of a peace agreement" Kastner, Legal Normativity in the Resolution of Internal Armed Conflict, 14.
} 
processes, though not all of them address the legal dimension of transition. For example, peacemaking and peacebuilding define the process of resolving armed conflicts and building sustainable peace, and even if such processes have received increasing legal regulation they are not legal notions as such. ${ }^{117}$ Therefore, this section will only analyze two concepts that, like jus post bellum, have been understood as defining the legal framework of transition to peace. One is the concept of transitional justice, which has been extensively developed in theory and practice. The other one is lex pacificatoria, proposed by Bell118 as an alternative concept to jus post bellum. This section will explore both concepts and their similarities and differences with jus post bellum, arguing why this last concept is preferable to the others for the purpose of naming the normative framework for the transition from armed conflict to peace.

\subsection{Transitional Justice}

The concept of transitional justice is rooted in political transitions from authoritarian regimes to democracy in Southern Europe in the 1970s, Latin America in the 1980s, and South Africa and Eastern Europe in the late 1980s and early 199os. ${ }^{119}$ For Teitel, one of the most authoritative authors on transitional justice, it "can be defined as the conception of justice associated with periods of political change, characterized by legal responses to confront the wrongdoings of repressive predecessor regimes." ${ }^{20}$ Developing this concept, the 2004 Report of the UN Secretary-General on the Rule of Law and Transitional Justice in Conflict and Post-Conflict Societies defines transitional justice as:

[...] the full range of processes and mechanisms associated with a society's attempts to come to terms with a legacy of large-scale past abuses, in order to ensure accountability, serve justice and achieve reconciliation. These may include both judicial and non-judicial mechanisms, with differing levels of international involvement (or none at all) and individual

\footnotetext{
117 Chetail, for example, defines jus post bellum as the law of peacebuilding, which implies that peacebuilding embodies the practice of building peace, and jus post bellum designates the norms applicable to such a process. See Chetail, 'Introduction,' 17.

118 Bell, On the Law of Peace.

119 Mark Freeman and Drazan Djukic, 'Jus Post Bellum and Transitional Justice,' in Jus Post Bellum. Towards a Law of Transition from Conflict to Peace, ed. Carsten Stahn and Jann Kleffner (The Hague: T.M.C. Asser Press, 2008), 213-14; Iverson, Jens, 'Transitional Justice, Jus Post Bellum and International Criminal Law: Differentiating the Usages, History and Dynamics,' 415 .

120 Ruti Teitel, 'Transitional Justice Genealogy,' Harvard Human Rights Journal 16 (2003): 69.
} 
prosecutions, reparations, truth-seeking, institutional reform, vetting and dismissals, or a combination thereof. ${ }^{121}$

Both definitions are related to the measures adopted by a society for dealing with past abuses, which can occur both in contexts of armed conflict or repressive political regimes. As such, transitional justice is a special form of justice for contexts of transition, ensuring individual criminal responsibility, reparations, truth, and institutional reforms, with a view to prosecute those responsible for abuses, offer a redress to victims, and prevent new abuses to occur. This view is shared with jus post bellum. However, even though both concepts relate to transitional contexts and have some common purposes, they are substantially different for at least three reasons.

First, the simplest difference between both concepts is that while transitional justice refers to both contexts of transition from dictatorship to democracy and from armed conflict to peace, ${ }^{122}$ jus post bellum only applies to the last scenario. Here, we have that transitional justice emerges as a concept during the transitions from dictatorship to democracy from the $197 \mathrm{Os},{ }^{123}$ whereas "the post-Cold War questions of transformative occupation, peacebuilding, and international territorial administration set the frame for jus post bellum." 124

Second, as showed in the definition above, transitional justice is focused on how a society deals with past human rights violations. In turn, jus post bellum is a broader concept and refers to the general transition from conflict to peace, going beyond human rights abuses. As Iverson states,

121 UN Secretary-General, 'Report of the Secretary-General on the Rule of Law and Transitional Justice in Conflict and Post-Conflict Societies,' para. 8.

122 On this point, Porter highlights that the academic study of transitional justice began with the transitions from dictatorship to democracy in Argentina, Brazil, Chile, East Germany, Greece, Hungary, Poland, Spain, Uruguay, and South Africa. Its reference to contexts of armed conflict takes place in DRC, Liberia, Sierra Leone, Sudan, Timor-Leste, and Uganda. Elisabeth Porter, Connecting Peace, Justice and Reconciliation (Boulder: Lynne Rienner Publishers, 2015), 10.

123 Teitel points out that the origins of transitional justice can be traced to wwI, but it becomes an international issue since the Allied-run Nuremberg trials in 1945. Then, it was in the last decades of the 2oth century that transitional justice took its contemporary form. See Ruti G. Teitel, Globalizing Transitional Justice: Contemporary Essays (Oxford: Oxford University Press, 2014), 49-56.

124 Jens Iverson, 'Contrasting the Normative and Historical Foundations of Transitional Justice and Jus Post Bellum: Outlining the Matrix of Definitions in Comparative Perspective,' in Jus Post Bellum: Mapping the Normative Foundations, ed. Carsten Stahn, Jennifer Easterday, and Jens Iverson (Oxford: Oxford University Press, 2014), 81. 
The substantive emphasis of jus post bellum is broader than human rights violations. It also clearly includes, inter alia, violation of the laws of armed conflict, the rights and privileges that spring from the laws of armed conflict, environmental law (including legal access to natural resources and regulating the toxic remnants of war), state responsibility outside the realm of human rights, recognition of states and governments, laws and norms applicable to peace treaties and peace agreements, peacekeeping, occupation, and post-conflict peacebuilding - laws that directly or through interpretation regulate and enable the transition to a just and sustainable peace. ${ }^{125}$

The third difference is referred to the content of both concepts. Transitional justice designates "the ways countries emerging from periods of conflict and repression address large-scale or systematic human rights violations so numerous and so serious that the normal justice system will not be able to provide an adequate response."126 In other words, transitional justice does not pretend to be a substantive framework, but the term to designate the specific model of justice adopted by a given society to deal with its past abuses. ${ }^{127}$ Conversely, jus post bellum is conceived as a set of norms or principles guiding the interpretation and application of law in contexts of transition from armed conflict to peace. ${ }^{128}$ It means, jus post bellum looks at offering a substantial framework for guiding transitions.

Notwithstanding their different scope of application, authors like Teitel consider the concept of jus post bellum vague and unnecessary, arguing that transitional justice already cover the matters that jus post bellum is intended to frame. ${ }^{129}$ Additionally, she affirms that jus post bellum is basically concerned with the restoration of the status quo ante, whereas transitional justice is more comprehensive to deal with the expectations and needs emerging in periods of transition. ${ }^{130}$ On this point, it is worth to mention that, as Walzer ${ }^{131}$ and

\footnotetext{
125 Iverson, 86.

126 International Center for Transitional Justice, What is Transitional Justice? Available at: https://www.ictj.org/about/transitional-justice (accessed on 1 April 2018).

127 Kai Ambos, 'The Legal Framework of Transitional Justice,' in Building a Future on Peace and Justice: Studies on Transitional Justice, Conflict Resolution and Development: The Nuremberg Declaration on Peace and Justice, ed. Kai Ambos, Judith Large, and Marieke Wierda (Berlin: Springer, 2009), 21.

128 May, 'Jus Post Bellum, Grotius, and Meionexia,' 25.

129 Teitel, Globalizing Transitional Justice, 143.

130 Ruti Teitel, 'Rethinking Jus Post Bellum in an Age of Global Transitional Justice: Engaging with Michael Walzer and Larry May,' European Journal of International Law 24, no. 1 (2013): 336 .

131 Walzer, Just and Unjust Wars. A Moral Argument with Historical Illustrations.
} 
Orend ${ }^{132}$ point out, even though a certain status ante should be restored at the end of armed conflict, just post bellum goes beyond, recognizing that sometimes the ante situation was precisely the very cause of conflict, and then it must be changed.

Contrary to Teitel's critics, jus post bellum is a broader concept, in which transitional justice can be integrated. Transitional justice has a concrete and limited scope, regarding the treatment of human rights past abuses, ${ }^{133}$ whereas jus post bellum is addressed to the overall restoration and construction of peace. Regarding this question, Turgis warns about the risk of broadening the concept of transitional justice. For her,

[...] it can be dangerous to broaden the scope of the objectives of transitional justice to extremely ambitious and varied aspirations, going from peace building to economic development. It is obviously a good thing if transitional justice can facilitate and promote other ambitions of a particular society. But transitional justice should not be used and thought of as a kind of magic wand [...] The risk of broadening the meaning of the concept is to dilute it and turning it into something meaningless [...] The core element of transitional justice is here: offering a "toolbox" filled with elements designed to deal with the violation of human rights from a predecessor regime to form the basis of an order to prevent their reoccurrence. ${ }^{134}$

In this way, having the elements discussed above, one can conclude that transitional justice and jus post bellum are two different and related concepts, which do not exclude each other. Transitional justice is a more developed field in theory and practice, but its aim does not comprise all the aspects of transition to peace. In this way, having jus post bellum the intention to cover transition to peace in a comprehensive way, transitional justice can be one of

\footnotetext{
132 Orend, 'Jus Post Bellum,' 122.

133 At this point, Kastner affirms that "Transitional justice is thus part of a bigger normative picture." In that sense, even if he does not use the concept of jus post bellum, he considers transitional justice only as a part of the normative framework on transition to peace, which he refers as much broader. Kastner, Legal Normativity in the Resolution of Internal Armed Conflict, 21.

134 Noémi Turgis, 'What Is Transitional Justice?', International Journal of Rule of Law, Transitional Justice and Human Rights 1(2010): 14. In this line, Iverson even sustains that the concept of jus post bellum should help transitional justice scholars to "refocus their field." Iverson, 'Contrasting the Normative and Historical Foundations of Transitional Justice and Jus Post Bellum: Outlining the Matrix of Definitions in Comparative Perspective,' 101.
} 
its components. ${ }^{135}$ Among the different matters involved in transition from armed conflict to peace, the treatment of human rights violations occurred during the conflict is an essential aspect for establishing a sustainable peace. That is the role for transitional justice. However, other aspects must be considered as well, as those related to the root causes of the conflict, the legal status of peace deals, the participation of different actors in peace talks, and environmental issues, for example. To frame all these aspects of transition to peace jus post bellum is a more capacious concept.

\subsection{Lex Pacificatoria}

The concept of lex pacificatoria was proposed in 2008 by Bell ${ }^{136}$ as an alternative to jus post bellum. ${ }^{137}$ She takes the parallel of the lex mercatoria, to refer to an emerging law of peacemakers as a set of legal practices, rather than a legal regime. For her, legal practices around peacemaking suggest a developing law that would be better captured by the term lex pacificatoria. In her words, lex pacificatoria is the outcome of the "interaction of both state and nonstate actors involved in the transition process, who respond to legal norms and try to craft solutions that comply with them in creative ways so as to respond to the distinctive dilemmas of peace-making."138

Contrasting lex pacificatoria to jus post bellum, Bell sustains that currently this lex is a matter of lege ferenda, "whose natural trajectory would seem to be toward a more established lex lata in the form of a fully worked out body of law capable of regulating transitions from conflict." In that sense, she suggests that "we might, from this perspective, view the lex pacificatoria as lex ferenda and jus post bellum as its possible future as imagined new lex lata." 139 Then, she sees jus post bellum rather as a "discursive project or a way of understanding the practical pressures which push for a distinctive normative revision." 140

135 On this idea, see Freeman and Djukic, 'Jus Post Bellum and Transitional Justice,' 226; Österdahl and van Zadel, 'What Will Jus Post Bellum Mean? Of New Wine and Old Bottles,' 193 .

136 Bell, On the Law of Peace.

137 Christine Bell explicitly presents lex pacificatoria "as an alternative to jus post bellum." Bell, 'Of Jus Post Bellum and Lex Pacificatoria: What's in a Name?', 192.

${ }_{13} 8$ Christine Bell, 'Lex Pacificatoria Colombiana: Colombia's Peace Accord in Comparative Perspective,' American Journal of International Law 110 AJIL Unbound Symposium on the Colombian Peace Talks and International Law (2016): 165.

139 Bell, 'Of Jus Post Bellum and Lex Pacificatoria: What's in a Name?', 193.

140 Christine Bell, 'Post-Conflict Accountability and the Reshaping of Human Rights and Humanitarian Law,' in International Humanitarian Law and International Human Rights Law, ed. Orna Ben-Naftali (Oxford: Oxford University Press, 2011), 369. 
Unlike jus post bellum, the concept of lex pacificatoria has had a very limited treatment in academic scholarship. Bell has devoted several works to its conceptualization, ${ }^{141}$ and even to its application to the Colombian case. ${ }^{142}$ However, few authors have discussed the notion of lex pacificatoria. ${ }^{143}$

Additionally, the main difference between the two concepts appears when jus post bellum is viewed by Bell as "a new coherent distinctive legal regime,"144 which, as argued above, is neither possible nor desirable. But if one looks at the other approaches to a definition of jus post bellum discussed in this chapter, there is no substantial difference with the concept of lex pacificatoria. Indeed, the understanding of jus post bellum as an ordering system, or a space of dialogue, or as an interpretative framework is connected to the view of lex pacificatoria as a developing set of practices on how the parties transiting from an armed conflict use legal norms to address their practical dilemmas of peace. ${ }^{145}$ Therefore, both jus post bellum and lex pacificatoria frame the context of actors dealing with legal obligations in their search for peace, in a dynamic where their peace efforts are shaped by law and their peacemaking practice creates new legal norms.

Finally, one could say that while jus post bellum is more focused on the normative framework applicable to transition, lex pacificatoria is mainly concerned with the practice of peacemakers when applying such a framework. Nevertheless, if one understands jus post bellum as an interactional framework, where norms and practice of actors involved in transition apply and create law at the same time, then, there is no real difference between jus post bellum and lex pacificatoria. In consequence, being jus post bellum the most developed concept, adding a new name to designate the same phenomenon seems unnecessary and it does not help to reaching common ways to understand the complex interaction between law and transition from armed conflict to peace.

141 Bell, On the Law of Peace; Christine Bell, 'The "New Law" of Transitional Justice,' in Building a Future on Peace and Justice: Studies on Transitional Justice, Conflict Resolution and Development: The Nuremberg Declaration on Peace and Justice, ed. Kai Ambos, Judith Large, and Marieke Wierda (Berlin: Springer, 2009), 105-26; Christine Bell, 'Peace Settlements and International Law: From Lex Pacificatoria to Jus Post Bellum,' in Research Handbook on International Conflict and Security Law. Jus Ad Bellum, Jus in Bello and Jus Post Bellum, ed. Nigel White and Christian Henderson (499-546: Edward Elgar Publishing, 2013); Bell, 'Of Jus Post Bellum and Lex Pacificatoria: What's in a Name?'

142 Bell, 'Lex Pacificatoria Colombiana: Colombia's Peace Accord in Comparative Perspective.'

143 Kreß and Grover, 'International Criminal Law Restraints in Peace Talks to End Armed Conflicts of a Non-International Character,' 44.

144 Bell, 'Lex Pacificatoria Colombiana: Colombia's Peace Accord in Comparative Perspective,' 165.

145 Bell, On the Law of Peace, 287-88. 
Although the concept of jus post bellum emerged within the context of transition from IAC s to peace, today there is a general opinion regarding its applicability to transition from NIACs. ${ }^{146}$ However, few works have specifically analyzed the particular conditions of jus post bellum in contexts of internal transition. ${ }^{147}$ Examining existing academic scholarship, only two articles are specifically devoted to assessing the application of the concept in NIAC s. ${ }^{148}$

In one article, Bartels discusses the temporal scope of jus in bello and jus post bellum, seeking to determine when do NIACs end, and whether both regimes apply simultaneously. ${ }^{149}$ Nonetheless, this contribution does not offer a systematic analysis of jus post bellum in NIAC s, but only the temporal dimension of the concept regarding the end of internal conflicts.

In the second article, Boon has proposed the most specific analysis on the application of jus post bellum in NIAC s that can be found in current academic scholarship in the field. ${ }^{150}$ She departs from minimizing the distinction

146 See generally Stahn, 'Jus Post Bellum: Mapping the Discipline(s),' 20o8, 106; Österdahl and van Zadel, 'What Will Jus Post Bellum Mean? Of New Wine and Old Bottles,' 179; Bartels, 'From Jus in Bello to Jus Post Bellum: When Do Non-International Armed Conflicts End?'; Boon, 'The Application of Jus Post Bellum in Non-International Armed Conflicts'; Chetail, 'Introduction,' 18; Dieter Fleck, 'Legal Protection of the Environment. The Double Challenge of Non-International Armed Conflict and Post-Conflict Peacebuilding,' in Environmental Protection and Transitions from Conflict to Peace: Clarifying Norms, Principles, and Practices, ed. Carsten Stahn, Jens Iverson, and Jennifer Easterday (Oxford: Oxford University Press, 2017), 203-19; Matthew Gillett, 'Eco-Struggles: Using International Criminal Law to Protect the Environment During and After Non-International Armed Conflict,' in Environmental Protection and Transitions from Conflict to Peace: Clarifying Norms, Principles, and Practices, ed. Carsten Stahn, Jens Iverson, and Jennifer Easterday (Oxford: Oxford University Press, 2017), 221-22.

147 To highlight the specificities of making peace in contexts of NIACs, Stahn even uses the expression "jus post bellum internum". Stahn, 'Jus Post Bellum: Mapping the Discipline(s),' $2008,106$.

148 Bartels, 'From Jus in Bello to Jus Post Bellum: When Do Non-International Armed Conflicts End?'; Boon, 'The Application of Jus Post Bellum in Non-International Armed Conflicts.' Even if in the Jus Post Bellum Project's 2017 volume two articles address matters related to NIACs, they do not analyze the application of jus post bellum as such on those contexts, but the legal framework for the protection of environment in contexts of NIACs. These two works are: Fleck, Gillet (2017) Fleck, 'Legal Protection of the Environment. The Double Challenge of Non-International Armed Conflict and Post-Conflict Peacebuilding'; Gillett, 'Eco-Struggles: Using International Criminal Law to Protect the Environment During and After Non-International Armed Conflict.'

149 Bartels, 'From Jus in Bello to Jus Post Bellum: When Do Non-International Armed Conflicts End?'

150 Boon, 'The Application of Jus Post Bellum in Non-International Armed Conflicts.' 
between international and non-international armed conflicts, ${ }^{151}$ based on three reasons. First, many IHL norms have been qualified as customary rules applicable to both types of conflict. Second, the development of international criminal justice "has blurred the relevance of the international/internal divide" extending the protection of individuals at all levels. And third, the application of IHRL to internal conflicts is convergent with its application to IAC s. ${ }^{152}$ With these arguments, Boon suggests "the creation of a unified set of jus post bellum principles that would apply regardless of the nature of the conflict."153

However, she admits that a unified jus post bellum can be problematic regarding matters which are highly dependent on internal political conditions. In this sense, she points out:

I make the case for a set of jus post bellum principles applicable to NIACs which would coincide with those applicable in IACs in areas governed by international humanitarian law, criminal law, and human rights, but which would differ with regards to rebuilding, reconstruction, and constitutional design. I argue that a narrower set of principles in these latter domains will improve the effectiveness and legitimacy of jus post bellum in the long run, and is justified by the principle of 'bounded discretion.'154

In other words, Boon proposes two levels of jus post bellum principles in the context of NIACs. A first set of principles is related to maters governed by IH RL, IHL, and ICL, which would be common for IAC s and NIAC s. A second set of principles would be specific for NIACs, regarding matters as reconstruction and political and institutional design, in which societies emerging from armed conflict need further leeway to find formulas according to their own dynamics. To apply this second set of principles she proposes the concept of "bounded discretion."

For her, the "bounded discretion" implies that jus post bellum should support the development of transitional instruments and structures under an

151 In the same way, Hofmann and Rapillard sustain that "The distinction between international armed conflict and NIAC has blurred over time. Nowadays, not only states, but also armed groups are considered to be holders of rights and obligations in internal conflict situations." Ursign Hofmann and Pascal Rapillard, 'Post-Conflict Mine Action: Environment and Law,' in Environmental Protection and Transitions from Conflict to Peace: Clarifying Norms, Principles, and Practices, ed. Carsten Stahn, Jens Iverson, and Jennifer Easterday (Oxford: Oxford University Press, 2017), 413.

152 Boon, 'The Application of Jus Post Bellum in Non-International Armed Conflicts', 262-63.

153 Boon, 265 .

154 Boon, 265 . 
international legal framework but leaving to local stakeholders the margin to define matters which are predominantly of domestic interest. In turn, the bounded discretion approach is supported by two principles: subsidiarity and margin of appreciation. ${ }^{155}$ The principle of subsidiarity implies that jus post bellum should prefer local formulas regarding social, economic, and political issues, and it would limit its role to offering general guidance under international standards. In the same line, the margin of appreciation refers to the state's level of autonomy to interpret its international legal obligations according to its domestic context. ${ }^{156}$

Considering the elements of this discussion, jus post bellum is clearly relevant to transition from NIACs to peace, and empirical research is required to identify how the theorical developments of the concept—even if addressed mostly to IACs - are reflected or contested by the practice of internal transitions. As delineated since the Introduction, current armed conflicts in the world are mostly NIACs, and most of peace processes and agreements are related to this kind of conflicts. ${ }^{157}$ Then, there are more practice on legal considerations around peacemaking and peacebuilding regarding NIACs than IAC s to empirically assess jus post bellum.

On this point, translating the concept of jus post bellum to NIAC s is a consequence of the increasing application of international legal elements to internal transitions, and not an assimilation of the automatic application of the three components of the law of armed force to both IACs and NIACs (because, for instance, jus ad bellum is not considered as applicable to NIAC s). Then, through the analysis of the Colombian case as a concrete transition from a NIAC, in the next chapters we will see a normative framework based on international law guiding legal and political decisions in the process of ending armed conflict and building sustainable peace, which is the object of jus post bellum.

\section{$7 \quad$ Conclusions}

This chapter was devoted to the conceptual foundations of jus post bellum. Notwithstanding there is not consensual definition, three approaches have been proposed to understand the concept: 1 ) as a new legal regime; 2) as an ordering system; and 3) as an interpretative framework. The first approach has

\footnotetext{
155 Boon, 266.

156 Boon, 266-267.

157 Escola de Cultura de Pau, Peace Talks in Focus 2018. Report on Trends and Scenarios, 11-12. See, supra, Introdución, section 4.
} 
been questioned by several authors, and such a conception of jus post bellum does not seem viable. However, the other two approaches offer useful elements for defining the content and scope of the concept, and they will be used as such in the next chapters of the book.

The notion of principles and the functional approach towards establishing sustainable peace helped to demarcate the object of jus post bellum. Such an object could be defined as offering a normative framework of principles guiding the transition from armed conflict to sustainable peace. In turn, sustainable peace has been conceived as composed by at least two conditions: addressing the root causes of the conflict, and observing international standards on human rights, IHL, and ICL. These elements define the rationale of jus post bellum and how it offers a more comprehensive legal framework for transition to peace than related concepts like lex pacificatoria and transitional justice.

Finally, jus post bellum, although mostly conceived from the perspective of IACs, is equally applicable to transition from NIACs. Regarding internal transition, the principles of jus post bellum require higher flexibility to address matters that are typically dependent on the specific political conditions of the context. Here, Boon suggests two levels of principles. First, principles dealing with violations of human rights and $\mathrm{IHL}$, where international law provides more exigent standards. Second, principles regarding matters as reconstruction and institutional design, where international law only can provide general guidelines, leaving domestic actors enough leeway to adopt their own approaches. Based on this assumption, the next chapters assess how jus post bellum is relevant and applicable to NIACs, through the analysis of the Colombian case. 